\title{
A Musical Fight between Soul and Body in 1600
}

Petersen, Nils Holger

Published in:

Journal of Early Modern Christianity

DOI:

10.1515/jemc-2014-0011

Publication date:

2014

Document version

Early version, also known as pre-print

Citation for published version (APA):

Petersen, N. H. (2014). A Musical Fight between Soul and Body in 1600. Journal of Early Modern Christianity, 1(2), 233-247. https://doi.org/10.1515/jemc-2014-0011 


\section{A Musical Fight between Soul and Body in 1600}

In his contribution to this volume, Jean-Louis Quantin points to the "ambivalent status" of Christian solitude in the seventeenth century, an ambivalence resulting from the question of whether it is better to flee the world or to contribute actively to its improvement by engaging in it. In this article I will discuss a similar paradox concerning withdrawal or engagement, in the context of the Roman Oratorians, by examining an early Baroque music drama, Rappresentatione di anima, et di corpo (The Play of Soul and Body, Rome 1600), ${ }^{1}$ composed by Emilio de' Cavalieri (c.1550-1602) to a libretto by Padre Agostino Manni. ${ }^{2}$ This famous and unique work, a pious musical exhortation to flee the world and its temptations, was performed in the oratory of the Oratorians who had engaged themselves

in the larger context of the Catholic Reform movement of the sixteenth century in bringing about religious revival through musical devotion. As we shall see, in the Rappresentatione the message of withdrawal was presented with musical and dramatic means designed to delight the audience.

The Rappresentatione has often been characterized as an oratorio or an early opera although the use of such terms must be deemed anachronistic for the time of its composition, since the oratorio and the opera were only gradually established as genres during the following half century. ${ }^{3}$ Most scholars' interest in the Rappresentatione has

\footnotetext{
${ }^{1}$ The Rappresentatione was edited by Alessandro Guidotti and printed in Rome in 1600. Facsimiles have been published in Rome in 1912, again in the UK in 1967. Recently a modern transcription and edition containing also an English translation of the text has been made available: Murray C. Bradshaw, ed., Rappresentatione di anima, et di corpo (1600) Emilio de' Cavalieri (Middleton, Wisconsin: American Institute of Musicology, 2007). Throughout this article, all citations of the Rappresentatione refer to this volume.

${ }^{2}$ The printed edition does not indicate the name of the librettist. Generally, it has been assumed that it was written by Padre Manni, and this has been conclusively shown in Warren Kirkendale, Emilio de' Cavalieri, Gentiluomo Romano: His Life and Letters, His Role as Superintendent of All the Arts at the Medici Court, and His Musical Compositions (Florence: Olschki, 2001), 246.

${ }^{3}$ There is a substantial literature on the genesis of these music historical terms and genres. In the context here I refer in particular to the discussion in Eyolf Østrem and Nils Holger Petersen, Medieval Ritual and Early Modern Music: The Devotional Practice of Lauda Singing in Late-Renaissance Italy, Ritus et Artes 1 (Turnhout: Brepols, 2008), Chapter 6: "The Historiography of Opera Reconsidered; Medieval Ritual, Confraternity Devotion and Music Drama," 201-42, in which also the Rappresentatione is discussed (205-10 and 224-29). For the development of the oratorio, I mainly refer to Howard E. Smither, A History of the Oratorio, 4 vols (Chapel Hill: University of North Carolina Press, 1977-2000), especially vol. 1. For the early history of the opera, it is more difficult to point to a generally accepted standard account. I refer in particular to Silke Leopold, Die Oper im 17. Jahrhundert, Handbuch der musikalischen Gattungen 2 (Laaber: Laaber-Verlag, 2004), Robert Donington, The Rise of Opera (London: Faber, 1981), F.W. Sternfeld, The Birth of Opera (Oxford: Clarendon Press, 1993; repr. 1995), and see also Lois Rosow, "Power and Display: Music in Court Theatre," in Tim Carter and John Butt, eds., The Cambridge History of Seventeenth-Century Music (Cambridge: Cambridge
} 
been directed toward understanding its place in the early development of these new genres, quite often arguing that it belonged to the oratorio tradition rather than to that of the opera. ${ }^{4}$ Since there were no well-defined genres of opera or oratorio at the time this distinction is historically meaningless. Indeed, in retrospect, the Rappresentatione can be seen to have traits in common with the oratorio as well as the operatic genre as both gradually emerged. ${ }^{5}$ It is undoubtedly a work which together with the music dramas for the Medici court in Florence by Jacopo Peri and Giulio Caccini, also composed around the turn of the century, had an important impact on the development of the new music dramatic genres during the first half of the seventeenth century.

Recent scholarship has broadened our understanding of the background for these developments, showing that music dramas in the new stile rappresentativo, traditionally associated mainly with the Florentine academies during the last decades of the sixteenth century and the mentioned music dramas around 1600, were performed by the boys in a religious youth confraternity (the Compagnia dell'arcangelo Raffaello in Florence) in which many of the members of Giovanni Bardi's and Jacopo Corsi's academies were also active (including Peri and Caccini), more than a decade before the mentioned courtly music dramas. ${ }^{6}$ This also provides a broader context also for Cavalieri's Rappresentatione. This was performed in the context of the Oratorians in Rome, in the oratory of the Chiesa Nuova, the church built for Filippo Neri (1515 95) and his Congregazione dell'Oratorio. Neri's mainly priestly congregation took its beginning in the 1550 s, receiving official Papal recognition in 1575. Neri had grown up in Florence and had his early education with the Dominicans in San Marco, Florence. He brought the Florentine tradition of vernacular religious song (the so-called lauda) to Rome, renewed this tradition through musical devotional ceremonies based to a high extent on the lauda tradition, resulting a.o. in the publication of several printed volumes of polyphonic laude, all with the intention to further

\footnotetext{
University Press, 2005), pp. 197-240.

${ }^{4}$ A position convincingly criticized in Kirkendale, Emilio de' Cavalieri, 233 94; see also Leopold, Die Oper, 61, and Østrem and Petersen, Medieval Ritual and Early Modern Music, 210 with further references.

${ }^{5}$ None of the early music dramas around 1600, which are traditionally described as the beginning of opera history (especially those by Peri and Caccini and even Monteverdi's Orfeo, Mantua 1607, the only of all these early Baroque music dramas to become a stable part of the modern opera repertory), were called operas. The preface "A'Lettori" to the printed edition of the Rappresentatione, however, does in (only) one place refer to the drama as "la presente opera",

"the present work." Even so, opera at this time has no genre to refer to (hence also Bradshaw's translation of "opera" as "work" in the preface), and the terms (otherwise) used in the preface for Cavalieri's Rappresentatione as well as for other contemporary music dramas are very general: "rappresentatione" ("play") and "compositione" ("composition"). See Bradshaw, ed., Rappresentatione, "A'Lettori," "To the Readers," 6-11.

${ }^{6}$ See Østrem and Petersen, Medieval Ritual and Early Modern Music, 211-24, for documentation, discussion and further references.
} 
devotion and piety for the Romans. In this environment, long after Neri's death, the music traditions of spiritual dialogues evolved into what has been termed the genre of the oratorio, toward the mid-seventeenth century. ${ }^{7}$

Naturally, the musico-cultural significance of Cavalieri's Rappresentatione must be interpreted in this context which, altogether, bridges the Roman Catholic Reform movement as manifested in Neri's congregation as well as the Florentine confraternal, academic and courtly culture, a culture which in itself should not be seen as divided in these distinct groups: on the contrary, many agents were active in courtly, academic as well as religious environments. ${ }^{8}$ Cavalieri himself moved in several social groups between Rome and Florence: he was employed by the Oratorio del Santissimo Crocifisso in Rome as a director of music between 1578 and 84, and apparently he was also a personal friend of Filippo Neri. He was employed at the Medici court in Florence from 1588 to (November) 1600 (that is several months after the performances of the Rappresentatione in Rome in February 1600) as superintendent of artists; during this time he composed a part of, and also directed, the famous intermedi performed in 1589 in connection with the wedding celebrations for Grand Duke Ferdinando de' Medici and Christine of Lorraine. He was also responsible for the music for another Medici wedding in October 1600, this time, however, his activities were marred by conflicts between Peri and Caccini leading him to leave Florence for good afterwards. During his time in Florence, he frequently visited Rome, and, apparently, also the oratory of the Chiesa Nuova. From before he went to Florence in 1588 and until shortly before his death, he also acted as a diplomat for the Grand Duke of Tuscany at the Roman curia, regularly sending secret reports to the court in Florence. ${ }^{9}$

In a recent article, Murray Bradshaw has discussed the theological contents of Cavalieri's

\footnotetext{
${ }^{7}$ For the Oratorians and Neri, see Smither, A History, I, 29-76, Arnaldo Morelli, Il tempio armonico: Musica nell'oratorio dei Filippini in Roma, Analecta musicologica, 27 (Laaber: Laaber-Verlag, 1991). For the polyphonic lauda in Florence in the sixteenth century and its appropriation in the collections of the Oratorians, see Østrem and Petersen, Medieval Ritual and Early Modern Music, Chapter 3, "Musical Style and Background of the Polyphonic Lauda 1500$1600, " 87117$.

${ }^{8}$ Østrem and Petersen, Medieval Ritual and Early Modern Music, esp. Chapter 4, “"Medieval' Devotion and Musical 'Avant Garde'," 119-63 and also 213-14, and see the "biography" of the mentioned Compagnia dell'arcangelo Raffaello in Konrad Eisenbichler, The Boys of the Archangel Raphael: A Youth Confraternity in Florence, 1411-1785 (Toronto: University of Toronto Press, 1998) which fully demonstrates how this and other confraternities cut across the various strata and societal groups in Florence.

9 Claude V. Palisca, "Musical Asides in the Diplomatic Correspondence of Emilio de' Cavalieri," The Musical Quarterly 49 (1963): 339-55; see also Smither, A History, I, 7980.
} 
Rappresentatione. ${ }^{10}$ Bradshaw argues that the libretto is specifically Catholic (and postReformation) in its content in spite of its scarcity of theological notions and references to traditional theological ideas or ecclesiastical measures (for which reason it has been characterized as theologically primitive or undenominational). Bradshaw points to its general position, that man can actually influence his salvation through good works as opposed to the Protestant notion of salvation as a pure gift of God's grace obtained only by faith (sola fide). ${ }^{11}$ He points out that "the libretto is very much like the type of sermon that grew up at the end of the sixteenth century;" ${ }^{12}$ it tends to avoid theological discourse and is primarily concerned with the moral battles of individual persons. Bradshaw sees in the structure of the play references to the church militant (the struggle of Soul and Body in Act II) and the church triumphant (in the descriptions of hell and heaven and the final praises of God with which the play ends). ${ }^{13}$ Although Bradshaw may overstate his case, ${ }^{14}$ it is obviously true that the play represents a Reform Catholic attitude, as is clear already from its performance context and is further emphasized by the prominent use of a contemporary lauda, "Anima mia che pensi" by Agostino Manni, previously printed and reprinted in collections of laude published by the Oratorians. In the Rappresentatione, however, this lauda was musically set anew by Cavalieri for the dialogue between Body and Soul in Act One. ${ }^{15}$

I believe that a fruitful approach to the theology or the worldview of the Rappresentatione is to look at what to a modern reader or audience may seem contradictory or strange. Although there is a modern performance history to point to, ${ }^{16}$ some very basic features stand out as particularly challenging in a modern context. It is striking that a message as austere as that of the Rappresentatione should be turned into a performance which appears as having been designed to a high degree to please the audience. To make this

\footnotetext{
${ }^{10}$ Murray C. Bradshaw, "Salvation, Right Thinking, and Cavalieri’s Rappresentatione di anima et di corpo (1600)," Musica Disciplina 52 (1998-2002): 233-50.

${ }^{11}$ Bradshaw, "Salvation," 234-35.

${ }^{12}$ Bradshaw, "Salvation," 236.

${ }^{13}$ Bradshaw, "Salvation," 240, 244, and 247.

${ }^{14}$ See for instance the statement "The final act is as clear a statement as possible of the Catholic view of 'Church,' and of the need of 'right thinking,' to believe in that Church" (Bradshaw, "Salvation," 247). The notion of the church is nowhere mentioned in the libretto. Explicitly, only hell and heaven, punishment and heavenly bliss and the struggle to overcome the temptations of the world, advised by allegorical figures including the "Angelo Custode," Guardian Angel (interpreted by Bradshaw as a representative of the Church triumphant, see 247).

${ }^{15}$ Bradshaw, ed., Rappresentatione, 33 37; see also Østrem and Petersen, Medieval Ritual and Early Modern Music, 224 with further references and Smither, A History, I, 84-88.

${ }^{16}$ Bradshaw, ed., Rappresentatione, "Introduction," IX; Kirkendale, Emilio de' Cavalieri, 464. In addition, it may be noted that the Rappresentatione was performed (for the first time) in Denmark during the Copenhagen Renaissance Music Festival in October 2010.
} 
seeming contradiction stand out clearly, I will now present some statements from the libretto itself juxtaposing them with statements from the editorial preface, which may possibly have been written by Cavalieri but at least must reflect his thoughts. ${ }^{17}$

The play opens, in the "proemio," with a dialogue (not set in music) between two young men ("Avveduto, e Prudentio giovannetti," "Caution and Prudence, Young Men") about man's relationship to the world, to materiality, but indeed to much more than that, to everything in the created world:

Caution: You, who in appearance seem to me to be a sensible and prudent young person, tell me, please, how does this mortal Life of ours that men value so much appear to you? What are your thoughts about it? I desire to know your opinion because I, too, would wish to live in a way so that, coming to my end, I do not find myself betrayed by false hope as happens to so many people.

Prudence: I cannot fully satisfy your desire, because my youthful years have not let me see much on this subject. Yet, from what I have been able to gather from afar and what I have learned from wise men who have passed through this life with a shrewd eye, it seems to me it is a show and appearance of vanity - like a beautiful garment covering the deformity of a sick body and a grassy meadow that hides a poisonous snake in its green weeds. What would you say that it was? ${ }^{18}$

In continuation, the two young men, who do not at all disagree, take turns adding up negative metaphors for human life on earth in general. Here follows a small extract of some of the sharpest of these: "a thick wood full of sharp thorns" ("un Bosco folto, ma pieno d'acute spine," Caution), "a dark vale of tears" ("una valle oscura di pianto,"

\footnotetext{
${ }^{17}$ Bradshaw, ed., Rappresentatione, "Introduction," IX.

18 "Av: Voi che all'aspetto mi parete sensato, e prudente giovanetto, ditemi di gratia, che vi pare di questa nostra Vita mortale, che gli huomini pregiano tanto? In che concetto la tenete voi? desidero il parer vostro: percioche anch'io vorrei viver' in modo, che giungendo al termine di essa, non mi trovassi, come á molti interviene, da falsa speranza ingannato. Pr: Io non posso sodisfare à pieno al vostro desiderio, perche gli anni miei acerbi non comportano, ch'io in questo soggetto habbi veduto molto: pure per quanto hò possuto odorare di lontano, e per quello che hò imparato da gli huomini savij, che l'hanno con occhio accorto trapassata; mi pare, ch'ella sia una mostra, et apparenza di vanità; una bella veste, che ricopre le deformità del corpo infermo: et un' herboso Prato, che con le verdi gramegne nasconde il velenoso serpe. E voi, che diresti che ella fusse?" Bradshaw, ed., Rappresentatione, 17 (text and translation).
} 
Prudence), "a flower that in a moment withers on the hedge" ("il Fiore, che sù la siepe in un tratto languisce," Caution), "a city filled with discord" ("una Città piena di discordie," Prudence), "a city of blood, a lust of the flesh" ("una Città di sangue: una Concupiscenza di carne," Caution), "Liken it to a Siren who sings, a harlot who entices, a magician who charms" ("Assimigliatela ad una Sirena che canta: ad una Meretrice che lusinga: ad un Mago ch'incanta," Prudence), "a sorrow that laughs" ("un Dolor, che ride," Caution), "a false life [...], and an inferno of the living" ("una Vita bugiarda: [...] et un' Inferno de' viventi," Prudence), "this miserable life is nothing but a funeral ceremony of living bodies, [...] a noble apparatus filled with worms" ("questa miserabil vita altro non è che una Pompa funebre di corpi vivi: [...] e un nobile Apparato, che si fa à vermi," Caution). ${ }^{19}$

After this Caution raises the question why "so many people hold it in such esteem, and enjoy it so much that they do not wish to die." ${ }^{20}$ Prudence points out that this is due to their sins having darkened their eyes. Again they are in complete agreement, and Caution concludes the argument with a longer passage which I quote in full:

How great would be the happiness of all, if they would rise from their senses to their intellects, would see that not riches, nor Pleasure, nor honor content the heart in this life, but only the good that is found with God, who would discover that Time flees in the twinkling of an eye, and with true Counsel would understand that this brief light of life disappears in a moment, that the Body with its senses hourly drives the Soul to a love of what is dirty, that Paradise shines over their head, that the Inferno burns under their feet, that the raving World deceives us and the enticing Life destroys us, and that, in effect, anyone who struggles valiantly on earth against the insults of these hateful temptations gains eternal and glorious crowns in heaven. ${ }^{21}$

\footnotetext{
${ }^{19}$ Bradshaw, ed., Rappresentatione, 17-19.

20 "che molti la tengono in tanta stima, et la gustano in modo tale, che non vorriano mai morire," Bradshaw, ed., Rappresentatione, 20.

21 “O qual felicità saria di tutti, se da I sensi s'alzassero dove è l'Intelletto! e quì vedessero che non richezze, non Piacere, non honore contenta il core in questa vita, ma solo il bene, ch'appresso à Dio si trova: e scoprissero, ch'Il Tempo fugge à un batter d'occhi: e co'l vero Consiglio apprendessero, che questa poca luce di vita in un momento tramonta: ch'il Corpo co' i sensi suoi sollecita ad ogn' hora l'Anima all'amor del fango. Che il Paradiso ne luce sopra il capo. Che l'Inferno ne arde sotto i piedi. Che il Mondo vaneggiando ne inganna, e la Vita lusingando n'occide. Et che in effetto qualunque contra gl'insulti dell'inimiche tentationi virilmente in terra combatte, eterne, e gloriose corone acquista nel Cielo.” Bradshaw, ed., Rappresentatione, 20.
} 
And then finally, Prudence announces the (musical) play that is about to be performed and which will constitute a "marvelous example" ("stupendo essempio") to show that the conclusion of the youths is true:

We shall see these very things happening, under the appearance of living persons, which, while they delight with new and strange images, at the same time will serve one idea, in which each person will be able to form a picture in his heart and recognize clearly that this Life, this World, these earthly grandeurs are truly dust, smoke, and shadow. Finally, that there is nothing firm or great except virtue, the grace of God, and the eternal Kingdom of Heaven. $^{22}$

What is striking is that these conclusions concerning the falsity of the senses and of pleasure are announced to be demonstrated through a "marvelous example" which will "delight with new and strange images." Delighting the audience was clearly an important concern for the composer and his editor (and spokesman) Alessandro Guidotti. In the Dedication to Cardinal Aldobrandino, Guidotti writes:

[...] the Rappresentatione di Anima, e di Corpo, performed this past February in Rome at the Oratory of the Vallicella with a great crowd and much applause - clear proof of how this style could move one also to devotion, because I have chosen it to be the first of all of them to be published so that both lay and religious people might enjoy it. ${ }^{23}$

Also the Preface ("To the Readers") emphasizes the importance of the delight of the

\footnotetext{
22 "E si vedranno venire inanzi le cose istesse, le quali sotto figura di persone humane apparendo, mentre con le nuove e strane imagini delettaranno, nell'istesso tempo serviranno per una Idea, dove ciascuno mirando puotrà formarsene un ritratto nel core, nel quale riconosca chiaramente, che questa Vita, questo Mondo, queste terrene Grandezze sono veramente polvere, fumo, e ombra: E finalmente poi che non ci è altro di fermo, ne di grande, che la virtù, la gratia di Dio, e'l Regno eterno del Cielo." Bradshaw, ed., Rappresentatione, 20.

23 “'...] la Rappresentatione di Anima, e di Corpo fatta il passato Febbraro in Roma nell'Oratorio della Vallicella, con tanto concorso, applauso, e manifesta pruova, Quanto questo stile sia atto à muover' anco à devotione: perche di questa hò fatta elettione, che sia la prima di tutte in istampa, acciò che il Secolare, e il Religioso ne possan godere." Bradshaw, ed., Rappresentatione, 4-5.
} 
performance; there is, throughout the preface, a strong focus on sensory quality, on what moves the senses, as can be seen in the following passage:

Wishing to stage the present work, or others like it, and to follow the instructions of Signor Emilio de' Cavalieri, and to see to it that this sort of music, revived by him, moves the different affections, like pity and joy, weeping and laughter, and the like [...]: as I say, wishing to stage this work, it is necessary that everything should be excellent, that the singer should have a beautiful voice, good intonation, and carry a steady tone, that she sing with feeling, softly and loudly, and without embellishments, and above all that she sing with the text so that it be understood, and that she accompany it with gestures and motions not only of the hands but also of steps, which are very effective means to move the affections. ${ }^{24}$

Altogether, the preface (as well as the rubrics for the performance in the score) makes it clear that the performance was staged, not just a sung performance as what later became the norm for oratorios. Some of the comments of the preface are not specifically about the Rappresentatione di Anima, et di Corpo but give advice about "similar plays with music." These general comments (some of them quoted above), however, are in complete agreement and continuity with what is said more specifically about the Rappresentatione, and it is sometimes difficult to tell whether a statement specifically concerns this work or is meant as a more general advice. Thus, for instance, it is stated that "such" plays should not last more than two hours, and that there should be a concern for variety in the performance in a number of ways due to the effects of variety upon the audience: the instrumentation is not determined in the score, in accordance with general music practice at the time, but "Signor Emilio" recommends that instruments are changed "according to the affect of the recitation;" performers are to be "attractively dressed and with variety." 25 Altogether variety is encouraged in mood, by way of change of tonality (mode) and of time

\footnotetext{
24 "Volendo rappresentare in palco la presente opera, overo altre simili, e seguire gli avvertimenti del Signor' Emilio del Cavalierie, e far si, che questa sorte di Musica da lui rinovata commova a diversi affetti, come à pietà, e à giubilo; à pianto, e à riso, e ad altri simili [...]: volendola dico rappresentare, par necessario, che ogni cosa debba essere in eccellenza, che il cantante habbia bella voce, bene intuonata, e che la porti salda, che canti con affetto, piano, e forte, senza passaggi, e in particolare, che esprima bene le parole, che siano intese, e le accompagni con gesti, e motivi non solamente di mani, ma di passi ancora, che sono aiuti molto efficaci à muovere l'affetto." Bradshaw, ed., Rappresentatione, 6-7.

${ }^{25}$ Bradshaw, ed., Rappresentatione, 6-7.
} 
and meter, by way of changing between various voices, high and low, as well as between solo and choral singing. Also the arias and music should be "adorned with echoes and as much as possible with other inventions, especially with dances which truly enliven these plays, as, in fact, has been judged by all the spectators." ${ }^{26}$ Indeed, the Rappresentatione ends with a dance, although this has been made optional:

The ending can be done in two ways, either with or without dancing. [...] If dancing is desired, you omit the eight-part verse, and begin to sing, "Chiostri altissimi, e stellate" [Highest and most starry cloisters]. The dancing begins with a riverenza and continenza, and then other slow steps follow, the couples interweaving and passing with dignity. The ritornellos are performed by four people who dance exquisitely with leaps and capers, and without singing. And so in all the strophes always vary the dance, and the four masters who are dancing should vary them, one time doing a gagliard, then a canario, and then a corrente, which go very well with the ritornellos. ${ }^{27}$

It is not possible in this short article to demonstrate how Cavalieri's music for the Rappresentatione corresponds to the general advice given in the preface. This is, however, quite obvious for any listener to the music (which has been recorded several times) or the music reader, not least through the variety of musical means which Cavalieri has employed. Not only does he use the new recitative style with accompanied monody adapted to the language and the mood of the words, but choruses in various styles, including the style of the polyphonic laude of the Oratorians. In the words of Howard E. Smither, it is "clearly the work of a skilled professional musician who is fully conversant with the newest musical styles and structures. [...] his mixture of recitative and dancelike aria styles in the solo passages creates an attractively varied impression." 28

\footnotetext{
26 “[...] adornate di Echi, e d'inventioni più che si può, come in particolare di Balli, che avvivano al possibile queste Rappresentattioni, si come in effetto è stato giudicato da tutti gli spettatori." Bradshaw, ed., Rappresentatione, 67. 27 "Il fine si puotrà fare in due maniere, ò vero con un ballo, ò senza: [...] Volendo finire co'l ballo, si lascierà di dire il detto verso à otto: e cominciandosi a cantare, Chiostri altissimi, e stellati, si cominci il ballo in riverenza, e continenza: e poi seguino altri passi gravi, con trecciate, e passate da tutte le copie con gravità: ne' Ritornelli si facci da quattro, che ballino esquisitamente un ballo saltato con capriole, e senza cantare: Et cosi segua in tutte le stanze variando sempre il ballo; e li quattro maestri, che ballano, puotranno variare, una volta gagliarda, un'altra Canario, e un'altra la Corrente, che ne' Ritornelli vi vengono benissimo." Bradshaw, ed., Rappresentatione, 8-11.

${ }^{28}$ Smither, A History, I, 87.
} 
It should be clear now how there seems to be a tension between the concern for the performance to please the audience and the contents of the libretto (an idea claimed by the two youths in the proem to be served by all the sensory means of the performance) which denounces all pleasure and enjoyment. Interestingly, this tension is not only between the contents of the work and the avant-garde aesthetic focus of the composer and the performance instructions, it is also appears to be an integral part of the actual dramaturgy and literary-musical composition of the Rappresentatione. This has already been noticed for the brief announcement made by the two youths at the end of the proem. But it also comes to the fore in the main musical setting, especially in Acts Two and Three, and therefore seems to be an integrated tension which is in need of being interpreted.

After the proem, Act One begins with a solo by the figure of Time (Tempo) set as a dark and gloomy recitative:

Time, time flies. Life wastes away, and now I seem to hear the final trumpet speaking come forth from the grave, oh scattered bones and dust. Arise again, Oh souls, and take on now your bodies. Come and speak the truth, whether it was a better idea to be a slave to the vane world or to the King of Heaven above? Open his eyes, so that each of us might learn and understand that this life is like a wind which flies past in a moment. Today it comes, tomorrow it dies. Today it appears, tomorrow it disappears, let each of us try, then, while we have time, to leave whatever is in the world, although it may be good in itself, and strive with heart and hand, because the fruit of good work is honor. ${ }^{29}$

\footnotetext{
${ }^{29}$ The English translation does not render the rhymes or the meter of the poem; therefore the English text has been quoted as prosa (although it was printed as a poem).

Il tempo, il tempo fugge,

La vita si distrugge;

E giá mi par sentire

L'ultima tromba, e dire,

Uscite da la fossa

Ceneri sparse, et ossa;

Sorgete anime ancora,

Prendete i corpi hor' hora;

Venite à dir' il vero,

Se fù miglior pensiero

Servire al Mondo vano,

O al Rè del Ciel soprano?

Si che ciascun' intenda,

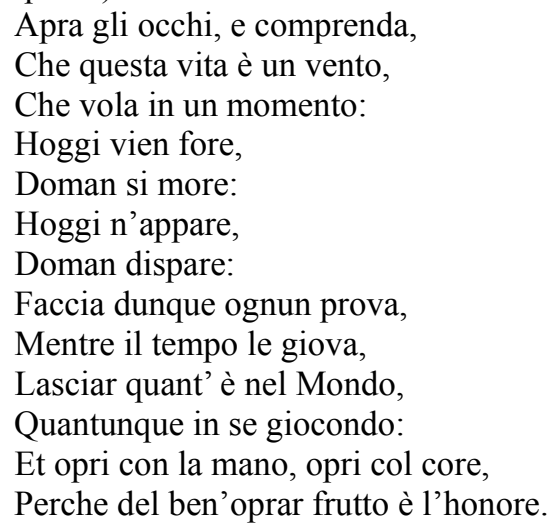

Bradshaw, ed., Rappresentatione, 170, (the libretto set in music with English translation is printed after the musical score, 169-93). 
This text introduced a somewhat more positive tone, underlining that life itself "may be good" and the following chorus and the solo by the figure of Intellect continue the theme of life's brevity, Intellect emphasizing that "every heart loves good" ("ogni cor' ama il bene"), pointing to all that cannot ultimately satisfy the desires of the heart, neither wealth, honour, nor pleasure. The only satisfaction is to be with God in heaven. ${ }^{30}$ This leads to the aforementioned lauda "Anima mi ache pensi" ("My soul, what are you thinking"), set here as a dialogue between the figures of Body and Soul, singing in each their style, Body in the sensuous recitativic style and Soul in the style of a (monophonic) lauda, each style reflecting the main positions of the two protagonist figures: Body tempted by the world, Soul critical of the temptations and pointing to God; finally Body accepts that one should not lose heaven because of the false desires of the world. ${ }^{31}$ Act One then closes with a chorus, almost consistently homophonic, praising God for his goodness and pity, echoing biblical psalms in inviting to praise the Lord through musical instruments, every tongue singing "Bless the Lord, for he is good." ${ }^{32}$

In Act Two, the actual struggle takes place. Pleasure and later World tempt Body and Soul, and the already established pattern is repeated: while Soul is (almost throughout) steadfast in rejecting the temptations, Body is much less so. It takes the advice of Guardian Angel for Body and Soul in the end to stand together rejecting the world, "away, away false World" ("via via Mondo fallace") whereafter they are given honour by Guardian Angel and invited to heaven by a chorus of Angels. Act Two closes with a chorus stating how it is "the adventurous fate of mortals" ("sorte aventurosa de' mortali") to "ascend to Heaven above" ("salir' al Ciel superno") from "earthly depths where death reigns" ("da gli abissi terreni, dove regna la Morte"). ${ }^{33}$ Within this dramatic centre of the Rappresentatione One notices that Pleasure's temptations first regard "little birds" who "sing in the trees," "simple fish" who "sparkle in the streams," "grassy meadows" which "laugh with colored mantle" and "woods and shadowy groves" which "rejoice and are festive." These

\footnotetext{
${ }^{30}$ Bradshaw, ed., Rappresentatione, 171-72.

${ }^{31}$ Bradshaw, ed., Rappresentatione, 172-73, musical score, 33 37; see also Østrem and Petersen, Medieval Ritual and Early Modern Music, 224.

${ }^{32}$ Bradshaw, ed., Rappresentatione, 173-74, musical score, 3844.

${ }^{33}$ Bradshaw, ed., Rappresentatione, 175-84, quotations 183 84, musical score, 50 101, quotations 95101.
} 
temptations are then characterized by Soul as "false pleasure." ${ }^{34}$ Among the words used by Pleasure, World, and Worldly Life in connection with the invitation to enjoy life while living on earth are: "allegrezza" ("joy" or "gaiety"), "diletto" ("delight”), "giubilo" ("joy"), and "piacere" ("pleasure"), "allegramente" ("with joy"), "allegra" ("joyful"). ${ }^{35}$

Act Three draws the conclusions from the previous acts. In a series of contrasting scenes, which give Cavalieri occasion to show the expressiveness of the new musical means he employs, Counsel and Intellect ask questions respectively to the Souls of the Damned at an open Mouth of Hell about eternal punishment and to the Blessed Souls in Heaven about the eternal rewards. This, of course, leads to new praises of God and to Intellect summing up the overall conclusion in a joyful recitative:

You who stand listening, why do you not rejoice? No more, no more be pensive! Let us all happily and joyfully celebrate with festivity. With joy let us sing! Flee far away from mourning! A festival, a festival all around! ${ }^{36}$

This leads to new choral praises and thanks, to a recitative by Soul exhorting all to praise and to "flee from sin." Finally, the Rappresentatione concludes in the festival (with dancing as discussed above, or the briefer conclusion without dancing). ${ }^{37}$ Here all sing together, including also the following passages:

Let all the world be filled with happiness and harmony. King of the world and great lords rejoice in your hearts. Each sex, each age, women and men, sing with young boys and maidens, joyful and beautiful songs. Air, earth, and sea resound with harps, lutes, organs, and trumpets, and soft breezes carry the gentle sound through the whole world, and,

\footnotetext{
${ }^{34}$ Bradshaw, ed., Rappresentatione, 176-77.

${ }^{35}$ Bradshaw, ed., Rappresentatione, 176-77, 179, 18081.

$36 \quad$ Voi ch'ascoltando state, Con festa giubiliamo, Perche non giubilate? Con giubilo cantiamo; Non più, non più pensosi: $\quad$ Fugga lontano il lutto: Tutti lieti, e gioiosi Festa, festa per tutto.

Bradshaw, ed., Rappresentatione, 191, musical score, 138.

${ }^{37}$ I only discuss the ending in case of the dance. However, as is easily seen, the main points of my discussion can carry over with only slight modifications for the version without the dance.
} 
touched by the sound, the heart feels the joys of love. ${ }^{38}$

It is noteworthy how the whole ascetic mood of the poem has changed radically in these statements, musically employing the newly developed musical means, and even using a number of the same terms as met with in the temptations of Pleasure, World and Worldly Life as "allegrezza," "allegra" and "giubilo." The question is how to understand the combination of asceticism, including the rejection of joy over even basic elements of Creation like birds, fishes and trees, and the extreme rejection of the trustworthiness of the senses, with the joyfulness over and sensory expression of the joy of divine salvation and moral good works.

An approach to an answer may be found in the general religious aesthetics which seem to have been developing in confraternities in Florence as well as in the Congregation of the Oratory in Rome. Eyolf $\varnothing$ strem and I have studied this in some cases based on records from the aforementioned Compagnia del'archangelo Raffaello in Florence where music practices at a high professional level became integral to the devotions of the confraternity especially during the decades around 1600. Similar ideas were also reflected more generally in the understanding of the devotional role of music in the practices of lauda singing at the time. ${ }^{39}$ The overall conclusion for the Raphael confraternity was a very clear impression that "sensuous qualities never seem to have been considered a religious problem in the Raffaello company (nor in other old youth confraternities). On the contrary they were rather seen as a means of enhancing the religious fervour and devotion of the youths." 40 Similarly, studies of prefaces and other contemporary commentaries to printed lauda books in the sixteenth to seventeenth centuries led to the conclusion that "the special ability of music to arouse devotion is a commonplace in these texts," ${ }^{41}$ just as melodies from worldly songs to a very high degree (although not everywhere) seems to

\footnotetext{
$38 \quad$ Tutto il mondo pieno sia D'ogni sesso, d'ogni etate

D'allegrezza, e d'armonia. Donne, e huomini cantate

Rè del Mondo, e gran signori Con fanciulli, e verginelle,

Giubilate dentro à i cori, Canzonette allegre, e belle.

Bradshaw, ed., Rappresentatione, 192.

${ }^{39}$ See Østrem and Petersen, Medieval Ritual and Early Modern Music, esp. Chapter 2, "The Conceptual Universe of

Lauda Practice," 43-86, and Chapter 4, "'Medieval' Devotion and Musical 'Avant Garde'," 119-63, with

documentation and many further references.

${ }^{40}$ Østrem and Petersen, Medieval Ritual and Early Modern Music, 163.

${ }^{41}$ Østrem and Petersen, Medieval Ritual and Early Modern Music, 81.
} 
have been sanctified by being used with sacred texts and thus taken away from bad secular uses. ${ }^{42}$

Thus one might suggest that the tension in an around the Rappresentatione to which I pointed earlier would probably not have existed for Cavalieri nor the congregation and audience for the two performances in the oratory of Chiesa Nuova. As soon as the sensory means are thought to be serving a religious, true purpose, the may be perceived no problem in employing these means. The modern question of how to ascertain that they actually do serve this purpose and do not lead astray seems only rarely to have been raised in these religious environments at this time.

This leads to the question whether the grand narrative of the long seventeenth century as presented by Hartmut Lehmann in this volume may shed light also on the particular literary and musical, or expressed more generally, aesthetic religious practices of which the Rappresentatione is an important example. Lehmann's overall understanding of the hardships of the period caused by climatic as well as politico-religious crises leads to a claim of a general pessimistic outlook on the world, either among people directly affected by this or affected by the general worries caused by the knowledge of the disasters in other places. Lehmann points to two main literary motives, the memento mori and the vanitas. Both motives are obviously very present in the Rappresentatione. Changes in religious life and attitudes were undoubtedly more radical in the Protestant areas of Europe than in the Catholic. Among other things, the Catholic liturgical continuity was much stronger than the Protestant, in spite of the centralizing efforts of the Council of Trent. But the religious culture of confraternities which, although subject to ecclesiastical (episcopal) control, was relatively independent of longstanding traditions and regulations. Therefore new devotional practices could more easily be introduced in such environments. The same was true also for the new order of the Jesuits. A new type of ceremonial in the sixteenth century, the Forty Hours Devotion, spread very fast in central Catholic areas, not least through the adoption by the Jesuits, the Oratorians as well as many confraternities. ${ }^{43}$

The negative outlook on life in the Rappresentatione comfortably fits into the general mood

\footnotetext{
${ }^{42}$ Østrem and Petersen, Medieval Ritual and Early Modern Music, 49-51, 71, and 91-97.

${ }^{43}$ Joseph Imorde, Präsenz und Repräsentanz: Oder: Die Kunst Jesu Leib auszustellen (Emsdetten: Edition Imorde, 1997); Nils Holger Petersen, "The Quarant'Ore: Early Modern Ritual and Performativity," in Performativity and Performance in Baroque Rome, eds. Peter Gillgren and Mårten Snickare (Farnham, Surrey: Ashgate, 2012): 115-33.
} 
of the times as described by Lehmann. However, the refuge taken to answers independent of Natural as well as political crises beyond the influence of humans in this case (and, as mentioned, also more generally in the broader Catholic confraternity context) was able to bring back the liveliness and aesthetic pleasure, within religious devotions. This corresponds very well to the way in which the genre of the oratorio developed as a kind of somewhat more ascetic religious opera to be performed during Lent and other times where opera was deemed inappropriate for religious reasons. And it even corresponds well to an anecdote about Filippo Neri told by Cavalieri in a letter of 1594. Cavalieri tells that Neri in his room made a priest dance to popular songs before giving them the benediction. ${ }^{44}$ The mildness of Neri and the seemingly very open-minded atmosphere at the popular outdoor spiritual devotions of the Oratorians, as emphasized by Smither, ${ }^{45}$ should also be contextualized by what may have been more austere internal practices. ${ }^{46}$ What seems to be clear is that both sides, austerity and delightful festivity, were common in these religious confraternity contexts, and as soon as a practice was understood as being truly religious, it was also acceptable for it to be aesthetically pleasing, and even festive.

Although the Rappresentatione seems to be a clear example of a religious contradiction in terms, preaching withdrawal from the world with delightful sensory means in the context of the Oratorians where engagement in the world was the accepted order, this seems not to have been the way it was perceived at the time. The sensory means were no longer seen as 'worldly' when they were (believed to be) employed in the service of devotion. Possibly also, withdrawal and engagement were not, in this context, considered as strict opposites, rather they may have been seen as complementary strategies for true devotion, religious engagement with the world appearing as a kind of metaphorical withdrawal.

\footnotetext{
${ }^{44}$ Palisca, "Musical Asides," 345-46.

${ }^{45}$ Smither, A History, I, 47-48, 51-52 and 80.

${ }^{46}$ Østrem and Petersen, Medieval Ritual and Early Modern Music, 100-102.
} 